\author{
Stanisław Cygan \\ Uniwersytet Jana Kochanowskiego w Kielcach \\ Instytut Literaturoznawstwa i Językoznawstwa \\ ORCID: 0000-0002-1108-3302; e-mail: stanislaw.cygan@ujk.edu.pl
}

\title{
Dziewiętnastowieczne słowniczki gwarowe księdza Władysława Siarkowskiego z perspektywy leksykograficznej
}

\begin{abstract}
Abstrakt: Przedmiotem opisu w artykule są dwa regionalne słowniczki z obszaru Małopolski środkowo-północnej autorstwa ks. Władysława Siarkowskiego. Rejestrują one dziewiętnastowieczną leksykę z regionu kieleckiego (okolice Kielc, Pińczowa).

Charakteryzując zbiorki wyrazów, uwzględniam następujące kwestie: a) czas powstania słowniczków; b) objętość; c) zasięg terytorialny; d) makrostrukturę słowniczków, e) mikrostrukturę słowniczków. Zawarty w nich materiał leksykalny stanowi przede wszystkim źródło do poznania najstarszego stanu gwar małopolskich (ściślej: Małopolski środkowo-północnej), źródło do badań gwar polskich w ogóle, ale daje także wgląd w pracę warsztatową niewykwalifikowanych leksykografów, pasjonatów, hobbystów, miłośników „rzeczy ludowych”, których działania przyczyniły się do zachowania i ocalenia od zapomnienia mowy mieszkańców wsi w dobie niewoli narodowej.
\end{abstract}

Słowa kluczowe: polska leksykografia gwarowa, region kielecki, słowniczki gwarowe, dialektyzmy leksykalne.

\begin{abstract}
The nineteenth-century dialect dictionaries by Father Wladysław Siarkowski - a lexicographical perspective. The article describes two regional dictionaries from the north-central region of Małopolska (Lesser Poland) by Father Władysław Siarkowski. They contain records of the nineteenth century lexicon from the Kielce Region (environs of Kielce, Pińczów). The lexical materials were published in 1878 and 1891.

When characterising sets of words, the following issues are taken into consideration: a) the time when the glossaries were compiled; b) the volume; c) the territorial scope; d) the macro-structure of the dictionaries; e) the micro-structure of the dictionaries. The lexical material included in the dictionaries is primarily a source of knowledge about the oldest status of the Małopolska dialects (more precisely, the north-central region of Małopolska) and a source of research into the Polish dialects in general. The author also provides insight into the technicalities of unqualified lexicographers, enthusiasts, hobbyists, lovers of folk artefacts, whose actions helped to preserve and save from oblivion the speech of rural residents in a time when Poland did not enjoy independence as a state.
\end{abstract}

Keywords: Polish dialect lexicography, the Kielce Region, dialect dictionaries, lexical dialectisms.

W najstarszym etapie rozwoju dialektologii polskiej, określanym jako przednaukowy, ważne miejsce zajmują monografie gwarowe uczniów Lucjana Malinowskiego ${ }^{1}$, autora pierwszej naukowej pracy dialektologicznej o gwarach śląskich (Malinowski 1873),

\footnotetext{
${ }^{1}$ Należeli do nich: J. Bystroń, J. Biela, S. Dobrzycki, W. Grzegorzewicz, W. Kosiński, S. Matusiak, R. Zawiliński nazwani przez S. Urbańczyka „niezłymi dialektologami” (Urbańczyk 1993,103).
} 
oraz słowniczki gwarowe dokumentujące leksykę mieszkańców wsi z różnych terenów Rzeczpospolitej. Jak podaje Stanisław Urbańczyk (1993, 24), były to „monografijki poszczególnych wsi lub małych okolic z dodanymi słowniczkami”. Badania Haliny Karaś wykazały, że do końca lat 70. XIX wieku opublikowano 22 słowniczki² (Karaś 2011, 24; zob. także Nowowiejski 2003, 2007, 2009a, 2009b, 2010a, 2010b, 2013, Wojtkiewicz 2003). Z kolei w latach 80. XIX wieku - 15, a między rokiem 1891 a 1899 - 26 (Karaś 2011, 71). Stanowiły one wyraz ludoznawczych zainteresowań inteligentów na prowincji, rezultat ich pracy terenowej prowadzonej $\mathrm{w}$ dobie niewoli narodowej. Owoce działalności tych społeczników, badaczy-amatorów, hobbystów przyczyniły się do pomnożenia dorobku polskiej leksykografii gwarowej i rozwoju dialektologii. Wielkim autorytetem cieszył się wśród nich Oskar Kolberg, który wyznaczał w swoim dziele Lud. Jego zwyczaje, sposób życia, mowa, podania, przysłowia, obrzędy, gusła, zabawy, pieśni, muzyka i tańce zadania badawcze służące opracowaniu serii monografii regionalnych składających się na etnograficzny obraz kraju³.

O tych entuzjastach pracy naukowej Ryszard Górski tak pisał:

Byli to prawdziwi fanatycy wiedzy i pracy, podejmujący się wielkiego dzieła nie tylko, by dać upust własnej pasji poznawczej i zaspokoić osobiste ambicje, lecz głównie, by spełnić patriotyczny obowiązek, przysłużyć się narodowi, badając i ukazując w przedziwnym świetle jego przeszłość, jego wielowiekowy dorobek w różnych dziedzinach oraz wzbogacając go nowymi osiągnięciami (Górski 1974, 10; por. też Skrukwa 2014).

Inteligencja na prowincji była przekonana o pilnej potrzebie dokumentacji ginącego folkloru, o tym, że „płody twórczości ludowéj są wielkiéj wagi, że codzień giną, a zatém zbierać je jak najprędzéj i co najpilniéj należy"4 (Karłowicz 1871, 3). Jej reprezentanci

${ }^{2}$ H. Karaś wymienia jeszcze dwa rękopiśmienne słowniczki, tj. bł. Edmunda Bojanowskiego o gwarze wielkopolskiej i Baltazara Działasa słowniczek gwary Piekar z dawnego powiatu oławskiego, wydany dopiero w II poł. XX wieku (zob. Karaś, 2011, 67; por. także 2012).

Akcja gromadzenia materiałów etnograficznych w terenie była podporządkowana takiemu sposobowi ich opisu. R. Zawiliński (1887, 3) pisał: „Ponieważ celem etnografii jest poznanie jakiejś grupy społecznej zupełne, więc gruntowne i wszechstronne, przeto celem etnografii polskiej jest poznanie narodu polskiego we wszystkich jego warstwach społecznych - we wszystkich prowincyach, powiatach, miasteczkach, wsiach i przysiółkach - gdzie tylko mowa polska się rozlega.[...] Przejść krok w krok kraj cały, przysłuchiwać się mowie, pieśniom, podaniom i przysłowiom i zarazem je zanotować, patrzeć na obyczaje i zwyczaje, na ludzi, ich otoczenie, życie i opisać to wszystko wiernie i zupełnie - tego jeden człowiek nie potrafi, ale potrafią setki, tysiące ludzi dobrej woli, rozsiane po całym obszarze kraju, po miasteczkach i po wsiach, jeżeli tylko, do jednego, jasnego zdążając celu, tych samych zechcą użyć dróg i sposobów, czyli tą sama posługiwać się będą metodą". Piśmiennictwo kieleckich inteligentów obejmowało albo całościowy opis kultury ludu, albo jakiś jej fragment (por. np. zbiorki słownictwa, przyczynki etnograficzne itp.).

${ }^{4} \mathrm{Z}$ kolei Jan Łoś, autor monograficznego opracowania gwary opoczyńskiej, oceniając dziewiętnastowieczny dorobek ludoznawczy, zwracał uwagę na to, że „[m]aterjały, zwłaszcza ludoznawcze, oddawna gromadzą się u nas w wielkiej obfitości, znać, że nie brak nam ludzi dobrej woli, którzy chętnie, jak mogą, służą nauce. [...] Materjały te jednak dla językoznawcy, historyka literatury, dziejopisa kultury i t.d., słowem dla każdego, kto chce z nich korzystać, aby na ich podstawie wnioski naukowe wysnuć, są prawdziwym morzem do wypicia - właśnie z powodu swej obfitości” (Łoś 1904, 177). 
rozumieli misję służby narodowi w dobie niewoli ${ }^{5}$, wykazywali postawę ofiarnictwa, odpowiedzialność za wspólnotę, mieli szacunek do wiedzy i pracy dla dobra ogółu' Ich prace służyły podtrzymaniu tożsamości w czasach zaborów. Dla przykładu wymieńmy tylko czterech z nich: przyrodnika-rolnika Stanisława Chełchowskiego (18661907)7, autora Zbioru pieśni ludowych z okolic Przasnysza i Zbioru prowincjonalizmów ludu przasnyskiego; notariusza cieszyńskiego dr. Andrzeja Cinciałę (1825-1898)8 ${ }^{8}$, który zebrał Pieśni ludu śląskiego i pozostawił rękopis Stownika dyalektycznego, czyli zbioru wyrazów staropolskich $i$ innych $w$ potocznej mowie używanych na Ślasku w Księstwie Cieszyńskiém, z dodatkiem przystowiów i frazeologii (wydany w sto lat po śmierci autora); wybitnego chirurga warszawskiego Władysława Matlakowskiego (1850-1895) $)^{9}$, autora Zbioru wyrazów ludowych ziemi czerskiej (Matlakowski 1891), który w trakcie leczenia gruźlicy odbywał wędrówki po wsiach górskich na Podhalu, rysował motywy, wzory budownictwa i zapisywał nazwy, a w efekcie opublikował Budownictwo ludowe na Podhalu (1892) i Zdobienie i sprzęt ludu polskiego na Podhalu (1901); oraz prawnika i urzędnika administracyjnego Karola Mátyása (1866-1925) ${ }^{10}$ zbierającego materiały ludoznawcze (bajki, podania tatrzańskie i sandomierskie, informacje o obrzędach i zwyczajach) na terenach eksplorowanych podczas pracy zawodowej, autora Stowniczka gwary ludu zamieszkujacego wschodnio-poludniowa najbliższa okolicę Nowego Sacza (wsie: Zawada, Nawojówka, Brzeziny, Kunów, Jamnica, Poręba, Bielowice i Dąbrówka Polska) (Mátyás 1891) i in.

$\mathrm{W}$ artykule charakteryzuję $\mathrm{z}$ perspektywy leksykograficznej dwa dawne zbiorki słownictwa gwarowego ${ }^{11}$, pozyskanego w trakcie badań terenowych i zapisanego przez innego przedstawiciela dziewiętnastowiecznej inteligencji, ks. Władysława Siarkowskiego (1840-1902) - kieleckiego regionalisty, społecznika, miłośnika folkloru, amatora archeologa, amatora dialektologa (Cygan 1998) i etnografa w sutannie. Stefan Żeromski $(1929,124)$ wymienia go wśród tych, którzy położyli wielkie zasługi dla gromadzenia „słowostanu” gwarowego.

Dla ks. Siarkowskiego Kielecczyzna była małą ojczyzną: urodził się 28 lutego 1840 roku w Imielnie, pow. i obwód kielecki; uczył się w Krakowie, najpierw w szkole elementarnej, później wydziałowej. Szkołę średnią - Gimnazjum Św. Anny - ukończył w 1859 roku. Po studiach w kieleckim Seminarium Duchownym i przyjęciu

${ }^{5}$ Na przykład A. Cinciała $(1998,2-3)$ pisał: „Niniejsza praca ma [...] pokonać fałszywe zapatrywania się Niemców i Czechów na nasz język i przypomnieć Polsce, że oderwana od niej latorośl przez tyle wieków nie uschła, że się zieleni, a obecnie nawet kwitnąć zaczyna”.

${ }^{6}$ Takie wartości inteligencji są przywoływane w różnych dyskusjach na temat kondycji tej grupy społecznej (por. Najder 2000; zob. też Filas, Janecki 1998; Surdykowski 1998).

7 Zob. biogram S. Chełchowskiego opracowany przez J. Krzyżanowskiego (1965a); (Kiniorski 1937).

${ }^{8}$ Zob. biogram A. Cinciały autorstwa przez J. Krzyżanowskiego (1965b) oraz J. S. Bystronia (1937).

9 Zob. biogram W. Matlakowskiego napisany przez A. Kowalską-Lewicką (1975; zob. także: Kapuścik 1995; Bartnicka 1997).

${ }^{10}$ Biogram K. Mátyása opracowany przez J. Krzyżanowskiego (1965c; por. też Żyga 1975).

11 Tekst ten pod względem kompozycyjnym jest podobny do mojego wcześniejszego artykułu (Cygan 2015). Przedmiotem omówienia były w nim m.in. materiały słownikowe $\mathrm{z}$ jednego dziewiętnastowiecznego słowniczka (z regionu pińczowskiego). W innym artykule pokazałem zmiany w zakresie leksyki kulinarnej z Pińczowskiego (por. Cygan 2003). 
święceń kapłańskich w roku 1864 został wikariuszem w Proszowicach. Dwa lata później pełnił obowiązki wikariusza w Kielcach. Od marca 1873 roku był sekretarzem, a od czerwca 1874 - regensem konsystorza kieleckiego. W roku 1877 otrzymał probostwo w Kijach, parafii w powiecie pińczowskim, zaś honorową kanonię w kapitule sandomierskiej rok później. Znał dość dobrze społeczność lokalną ze względu na pełnioną posługę kapłańską. Poważna choroba płuc zmusiła go w roku 1900 do rezygnacji z piastowanych urzędów kościelnych. Zamieszkał u swego krewnego, dr. Janiszewskiego w Grodźcu, gdzie zmarł 23 marca 1902 roku. W kościele kijskim znajduje się epitafium ks. W. Siarkowskiego.

Oto znamienne wypowiedzi proboszcza kijskiego, ilustrujące jego ludoznawcze poszukiwania, zawarte w listach do O. Kolberga:

[4 IV 1876 r.] Zająłem się skrzętnie badaniem właściwości języka ludu stron kieleckich i zebrałem słowniczek wyrażeń jego, jak również zwrotów mowy. [...] Najwięcej mię ucieszyło, iż wynalazłem wyrażenia dziś w książkowym języku nie używanych dualisów zaimka osobowego: naju, nama, wa (Kolberg 1965, 592).

[10 XI 1878 r.] Zbieram obecnie materiały etnograficzne z okolic Pińczowa, gdzie otrzymałem administrację probostwa Kije i dokąd z Kielc co drugą niedzielę i w święta uroczystsze zjeżdżam dla załatwienia interesów dziekanowych. [...] Wikariuszowi memu dałem zlecenie, aby także zbierał z ludu wszystko to, co może pochwycić, gadki spisuje mi zaufany chłopak wiejski (Kolberg 1966, 177).

Te dwa regionalne słowniczki są cennym źródłem dialektalnym. Zostały włączone do Słownika gwar polskich J. Karłowicza (SKarł) oraz nowego słownika gwarowego (SGP) przygotowywanego przez Zakład Dialektologii PAN w Krakowie. Z analizy Wykazu skróceń słownika gwar polskich J. Karłowicza (SKarł, I, 457-458) wynika, że ks. W. Siarkowski przekazał uczonemu dwa rękopiśmienne słowniczki: słowniczek gwary kieleckiej i słowniczek gwary od Mstyczowa (wieś w pow. jędrzejowskim, dekanat sędziszowski); słowniczek pińczowski jest drukowanym źródłem dialektograficznym. Nieznane są losy drugiego dzieła. We Wstępie do słownika J. Karłowicza (SKarł, I, [bez paginacji]) znajdują się podziękowania dla osób, które dostarczyły „większych lub mniejszych przyczynków słownikowych oraz ustnych i listownych objaśnień", m.in. dla ks. W. Siarkowskiego. Trzeba dodać, że niektóre wyrazy hasłowe mają poświadczenie tylko ze słowniczka pińczowskiego ks. Siarkowskiego: babiczka 'krzew róży polnej' (SKarł, I, 29); bliźnia 'sąsiadka' (SKarł, I, 90); bramować 'dopiekać, docinać' (SKarł, I, 115); choropiać 'swarzyć się’ (SKarł, I, 199); czajkiem 'niepostrzeżenie' (SKarł, I, 269); dworować 'wychodzić na potrzebę na dwór' (SKarł, I, 403); dychawka 'duszność' (SKarł, I, 407); gorlić się 'przegorlać się' = przemawiać (SKarł, II, 106); kozidry 'sosny przeznaczone na wyrób gontów' (SKarł, II, 457); kralaśny 'kulawy' (SKarł, II, 468); ochędożny 'porządny' (SKarł, III, 381); ochmiały 'plewy z prosa' (SKarł, III, 383); ostrewka 'blaszka okrągła, mosiężna, zwykła ozdoba na chomątach' (SKarł, III, 473); ozdoba 'omasta, okrasa' (SKarł, III, 490); pałęga 'miejsce niezarosłe w ogrodzie' (SKarł, IV, 21); pardać 'wałęsać się', 'włóczyć się’ Mst. (SKarł, IV, 39); pasielaki 'dzieci, które ciągle trzeba karmić' (SKarł, IV, 46); paszczyska 'miejsce 
wśród lasu, pokryte błotem’ (SKarł, IV, 53); perczaki = groch polny (pisum arvense) (SKarł, IV, 72); pokorać 'podołać' (SKarł, IV, 225); przegorlać się 'przemawiać się' (SKarł, IV, 373); przemarcować 'przemianę zrobić' (SKarł, IV, 338), rudawizna 'nieczystość w przenośnem znaczeniu = grzech' (SKarł, V, 70); salantować' 'obnosić się, że ktoś jest skąpy' (SKarł, V, 98); sieczenica 'karma dla bydła, złożona z wyki, grochu, owsa' (SKarł, V, 121); skórny 'skłonny' (SKarł, V, 151); smagło 'pospiesznie, raźno' (SKarł, V, 175); stranie 'wymioty' (SKarł, V, 242); szory 'obcięta słoma w poszyciu dachu' (SKarł, V, 312); tredać 'marudzić' (SKarł, V, 418); wista 'wszelki wylew wód na wiosnę' (SKarł, VI, 131); wiśtaka = 'chuśtawka' (SKarł, V, 132); zaduszki (nazwa kościelna) = 'świetlaki’ (SKarł, VI, 264); zgrędzić a. grdykać, grdękać = 'pić wódkę (koło Kielc)' (SKarł, VI, 377); zakatusić się 'zamglić' (SKarł, VI, 286); zatrawniczyć się 'pokryć się zielonością' (SKarł, VI, 329); zazoga 'grunt opoczysty, opoka' (SKarł, VI, 340); zchodek 'koniec' (SKarł, VI, 352).

Charakteryzując z perspektywy leksykograficznej wymienione słowniczki, nazywane w XIX wieku abecadłowymi zbiorami wyrazów ludowego języka, spisami wyrazów $i$ wyrażen, zbiorami wyrazów ludowych, słownikami gwary ludu ${ }^{12}$, biorę pod uwagę: a) czas ich powstania; b) objętość (liczba wyrazów hasłowych); c) zasięg terytorialny (geograficzny); d) ich makro- i mikrostrukturę. Te opracowania to nieduże słowniki, ułożone w porządku alfabetycznym, które niekiedy były dodatkami do monografii poszczególnych wsi i ich okolic (słowniczek kielecki) ${ }^{13}$. Zawarty w nich materiał leksykalny ma dużą wartość dokumentacyjną: może posłużyć do rekonstrukcji gwary kieleckiej (okolic Kielc i okolic Pińczowa) i obrazu życia i kultury mieszkańców dziewiętnastowiecznej wsi. Umożliwia też poznanie warsztatu leksykograficznego ich twórców, niewykwalifikowanych leksykografów ${ }^{14}$ i ewolucji praktyki leksykograficznej (zob. np. Sokólska 2013). Autorzy XIX-wiecznych słowniczków mieli świadomość niedoskonałości swojego warsztatu, czego przykładem mogą być słowa Andrzeja Cinciały:

Jeżeli praca niniejsza nie odpowie zupełnie wymaganiom dzisiejszego słownikarstwa dyalektycznego, to proszę zauważyć, że słownikarstwo przed 35 laty, gdzie pracę moją rozpocząłem, na innych jak obecnie spoczywało zasadach, a że jedynym celem tej pracy było i jest, aby posłużyła jako materyał przy układaniu nowego słownika polskiego (Cinciała 1998, 4).

Ja nie miałem zamiaru podawać do druku tej pracy, chciałem tylko nagromadzić i opracować materiał tak daleko, aby przyszły leksykograf mógł z mojej pracy korzystać, bo nie

12 Zob. wybrane przykładowo słowniczki wyrazów gwarowych autorstwa A. Wagi (1860), Z. Glogera (1893), W. Matlakowskiego (1891, 1894), J. Złoży (1891), L. Rzeszowskiego (1891), J. Bieli (1891), B. Dembowskiego (1891).

13 Słowniczek kielecki został umieszczony w 1. części publikacji ks. W. Siarkowskiego Materiały do etnografii ludu polskiego z okolic Kielc jako część rozdziału 6. Gwara ludowa, punkt g, s. 37-49 wraz z Dodatkami (1. wyrazy ekspresywne - s. 49, 2. nazwy roślin [22 nazwy] i informacje o magicznym działaniu trzech roślin - s. 49-51, 3. przezwiska nadawane mieszczanom przez lud - s. 51).

${ }^{14}$ Zob. hasło słownikarz, słownikopis 'układacz słownika, lexikograf' (Linde 1951, V, 325); leksykograf 'autor słownika' (SWil 1861, I, 582) słownikarz, v. słównikarz, v. słownikopis 'człowiek trudniący się układaniem słowników, leksykograf’ (SWil 1861, II, 1512). 
będąc filologiem z powołania, nie czułem się też na siłach postawić pracę moją na wysokości badań językoznawczych (Cinciała 1931, 126-127).

\section{A. Czas powstania słowniczków}

Charakteryzowane słowniczki zostały opublikowane w 1878 r. (kielecki - SKiel) i w 1891 r. (pińczowski - SPińcz). Powstawały one w czasie, kiedy dialektologia była niejako u źródeł, kiedy dążono do „przezwyciężenia inercji zbieractwa” i powolnego formowania jej naukowej problematyki ${ }^{15}$.

\section{B. Objętość słowniczków}

Różnią się one liczbą haseł: obszerniejszy jest słowniczek kielecki, bo zawiera 355 wyrazów, mniejszy zaś pińczowski, liczy bowiem 162 wyrazy. Średnia liczba wyrazów hasłowych to 259 .

\section{Zasięg geograficzny}

Z punktu widzenia kryterium geograficznego słowniczki mają zasięg regionalny i lokalny ${ }^{16}$ (Woźniak 2000). Zawierają słownictwo z okolic kieleckich ${ }^{17}$ i okolic Pińczowa (przeważnie z parafii Kije pod Pińczowem):

Niniejszy zbiór wyrazów i wyrażeń ludowych, przeważnie pochodzi z parafii Kije pod Pińczowem, które przy załatwieniu różnych czynności duchownych, spisywałem sobie z całemi zdaniami, jakie z ust jedynie starych ludzi, nie umiejących czytać, posłyszałem (Siarkowski 1891, 335).

15 Takie sformułowania pojawiają się w artykule prof. W. Doroszewskiego $(1953,6)$

${ }^{16} \mathrm{~K}$. Woźniak wśród różnych źródeł leksykograficznych wymienia: 1) duże słowniki osobno wydane drukiem; 2) wiele mniejszych słowników i słowniczków gwarowych drukowanych w czasopismach i opracowaniach monograficznych; 3) dużej i średniej wielkości słowniki rękopiśmienne; 4) samodzielne atlasy gwarowe (Woźniak 2000, 18-19). Jak podaje K. Woźniak, ze względu na zasięg geograficzny słowniki gwarowe można podzielić następująco: a) ogólnogwarowe - dotyczące obszaru wszystkich polskich dialektów (o zasięgu ogólnopolskim); b) dialektalne - obejmujące cały dialekt; c) regionalne (o zasięgu regionalnym) - dotyczące większych zwartych części dialektów lub ich pogranicza, np. Kielecczyzna, Podkarpacie, Ostródzkie, Warmia i Mazury; d) lokalne - mniejsze od regionu, np. słowińskie, ok. Podegrodzia albo odnoszące się do pojedynczych wsi, jak: Domaniewek, Dzierżysławice, Podróżna, Więciórka (Woźniak 2000, 18).

${ }^{17}$ Ks. W. Siarkowski $(1878,17)$ pisał: „Spostrzeżenia swoje nad właściwościami gwary ludu okolic kieleckich czyniliśmy we wsiach parafii kieleckièj [...], we wsiach rozłożonych u pasma Gór Świętokrzyzkich [...], następnie we wsiach na trakcie ku Chmielnikowi położonych [...], wreszcie w Staro-Chęcinach, Wólce Kłuckièj, Tumlinie, Zagnańsku i Suchedniowie”. Warto dodać, że w rozdziale tym umieścił autor frazeologizmy, wyrazy polisemiczne, synonimy oraz wyrazy znane w Krakowskiem, których ks. Siarkowski nie słyszał na Kielecczyźnie: w punkcie c) „spis ciekawszych zwrotów mowy” (s. 26-30), punkcie d) ,wyrazy mające dwojakie lub kilkorakie znaczenie” (s. 30-32), e) „wyrazy i wyrażenia mające spólne znaczenie”, f) „spis wyrazów wymienionych w dziele p. Kolberga: Lud seryja VIII str. 303-329, których dotąd nie zdarzyło nam się słyszeć w okolicach kieleckich” (s. 32-33). 
Słowniczki nie podają zasięgu geograficznego każdego wyrazu hasłowego. Tylko niektóre z nich są dokumentowane krótkimi, jednozdaniowymi kontekstami słownymi. Stefan Żeromski tak pisał o kieleckim słowniczku ks. W. Siarkowskiego:

Przytoczyłem tutaj nieco luźnych wyrazów ze słowniczka mowy świętokrzyskiej, zebranego przez ks. Władysława Siarkowskiego, który to słowniczek jest małą i ułamkową cząstką bogatej mowy tamtejszej (Żeromski 1929, 129).

\section{Makrostruktura słowniczków ${ }^{18}$}

Na jakość opisu leksykograficznego rzutuje ich popularnonaukowy charakter oraz to, że - jak wspomniano - stanowią one dzieło zbieraczy amatorów, hobbystów, niewykształconych leksykografów, którzy mogli korzystać ze słownika B.S. Lindego, późniejszego - wileńskiego, a także słowniczków zamieszczonych w niektórych monografiach regionalnych Oskara Kolberga, np. w tomie II: Sandomierskie, IV: Kujawy, VIII: Krakowskie IV, XLIII: Śląsk, XLVIII: Tarnowsko-Rzeszowskie ${ }^{19}$ itd.

\section{Układ haseł}

Zachowuje się na ogół w układzie haseł porządek alfabetyczny, choć niekiedy jest on nieprzestrzegany, np.:

SKiel: B: bojaźność, bór, borki (SKiel, 37); G: gołda, godzić się (SKiel, 39); P: patraki, pęcyna, pęcynka, perkać (SKiel, 43); przewatkonić, przetrzé́wić, przyciuknać (SKiel, 43), przyług, przeziéradko, psibiskunt, psuć się, przywiśnie, psy, puchać (SKiel, 44); S: sady, sadzonka, satrzyć, ścibło, ściegny, ściubać, scutka, seremno, siedziárka, siepać (SKiel, 44); U: upsnać się, uświarcyć, ustrulgać się (SKiel, 46).

\section{Zasady hasłowania}

W zakresie hasłowania wyrazów można wskazać pewne prawidłowości:

a) rzeczowniki zdrobniałe występują niekiedy przy haśle podstawowym:

${ }_{18}$ Pojęcie makro- i mikrostruktury słownika przyjmuję za P. Żmigrodzkim (2003, 52). Zob. także elementy dotyczące makrostruktury i mikrostruktury słowników w pracy W. Miodunki (1989, 255-256). Makrostruktura słownika to wzajemny układ jego artykułów hasłowych (alfabetyczny, gniazdowy lub pojęciowy, problemy hasłowania, tzn. różnych typów haseł, hasła i podhasła. Mikrostruktura zaś to wewnętrzna struktura artykułu hasłowego, a więc wyodrębnienie jego obowiązkowych składników, określenia ich kolejności i sposobu realizacji. Artykuł hasłowy, in. hasło, to wyodrębniona graficznie jednostka opisu słownikowego rozpoczynająca się od wyrazu hasłowego i stanowiąca sekwencje ściśle określonych elementów. Słownik to zbiór artykułów hasłowych ułożonych w określonym porządku.

19 Zob. informacje na ten temat w artykułach A. Tyrpy (2015) i W. Wysoczańskiego (2015). 
SPińcz: kłys, kłysek 'kłos, kłósek': Święty Jàn kłysek zgion (przysłowie rolnicze) (SPińcz, 337); chwajdàt, vel chwajołek, krzaczek kapusty (SPińcz, 336);

b) pary hasłowe tworzą warianty językowe [fonetyczne, słowotwórcze, fleksyjne, leksykalne]:

SKiel: bocula (boczula) (SKiel, 37); bestać (besztać) (SKiel, 36), bojazyć (bojarzyć) (SKiel, 37), łabcyć się vel tapcyć (SKiel, 40), medel vel mędel (SKiel, 41), morka vel pomoscyzna (SKiel, 41), murawne vel murawina (SKiel, 41), neta, necie (SKiel, 41), niezbędnica vel brzydnica SKiel, 41), oddynkować vel odtynkować (SKiel, 42), pastorka, pastucha (SKiel, 43), słapcie vel karpie (SKiel, 45), szczyk, scyk (SKiel, 45), szczypecka vel scypecka (SKiel, 46), swałek vel swałka (SKiel, 45), trzynać vel trzunać (SKiel, 46), widma vel wydma (SKiel, 47), zchorzeć, zachorzeć (SKiel, 48),

SPińcz: alamuśny vel halamuśny (SPińcz, 335); bańduch vel bańdos (SPińcz, 335); grdykać, v. grdękać, zgrzędzić. Koło Kielc - pić wódkę (SPińcz, 336);

c) w jednym artykule hasłowym umieszczono wyrazy należące do tej samej rodziny wyrazów, reprezentujące różne części mowy (rzeczownik, czasownik, przymiotnik, także formy prefigowane) - zatem niekiedy w jednym ciągu są umieszczone dwa (rzadko trzy) artykuły hasłowe, są tu wyrazy należące do tego samego pola semantycznego (częste) lub różnych pól (rzadkie) ${ }^{20}$, np.:

SKiel: betkotać, sub. betkot vel betkocina (SKiel, 36), bór, borowy (SKiel, 37), chamrać, pochamrać (SKiel, 37), granda, grandować (SKiel, 39), grdyk, grdykać (SKiel, 39), grzdula, grzdulnąć (SKiel, 39), obraźnik, obraźnicka (SKiel, 41), ślaja, ślajać (SKiel, 45), słonie, posłonne, słonne (miejsce) (SKiel, 45); wybiegać - rosnąć; wybiegly, $-a,-e$, rosły (SKiel, 47).

SPińcz: kalanica, vel kalemba (SPińcz, 336), gorlić się, przegorlać się (SPińcz, 336), przekomarzać się, kłócić się; przekomary, kłótnie (SPińcz, 338).

\section{E. Mikrostruktura słowniczków}

Wśród różnych informacji, które stanowią komponent artykułu hasłowego, obok definicji słownikowej zamieszczone są informacje gramatyczne, te odnoszące się do zasięgu użycia danego wyrazu (niekiedy dość ścisła lokalizacja faktów językowych) oraz do różnych sposobów kwalifikowania leksyki gwarowej. Ponadto możemy niekiedy też znaleźć informacje etymologiczne i odsyłacze.

20 Ze słowniczka Oskara Kolberga z Sandomierskiego, który znajduje się w części Język w tomie jego dzieł pt. Sandomierskie (Kolberg 1865, 260-266), podajemy następujące przykłady: bacenie, bacyć (Kolberg 1865, 260), bajbuga, bajbucyć (Kolberg 1865, 260), chytry, chytrość (Kolberg 1865, 261), judy, oszusty, judzić, wyłudzać, juda, judas, przebiegły jucha, wykpisz z czego (L. Juda, Judasz) (Kolberg 1865, 262), krześnica, krześniak (Kolberg 1865, 262), omasta, omaścić (Kolberg 1865, 263), ożydla, klapy u sukmany, ożydza, całe ubranie na piersiach dające się ująć rękoma (Kolberg 1865, 263). 


\section{Definicje słownikowe}

W omawianych słownikach spotykamy różne sposoby definiowania wyrazów hasłowych (wyjaśnienie treści znaczeniowej nazwy: wyrazy jedno- i wieloznaczne, określenie zakresu użycia wyrazu czy podanie wyrazu bliskoznacznego [synonimu]):

a) definicje realnoznaczeniowe:

SKiel: ceta - tęcza na niebie (SKiel, 37), chorem - (przezwisko pogardliwe), duży człowiek, olbrzym, obacz: wielgus, zmacha (SKiel, 37), forsa - przykład, np. dziecko ma do złego forsę z ojca. (SKiel, 39), kajda - torebka z drzewa, używana przez kosiarzy do chowania osełki. (SKiel, 40), micha - (pogardliwie) kobièta nierodząca, bezdzietna (SKiel, 41), owały - zaspy śniéżne (SKiel, 42), sieroga - chmurki małe, jak dym rozwleczone nad ziemią, z których dészcze powstają (SKiel, 44), spława - wierzchołek drzew (SKiel, 45), szczyk, scyk - pierwsza trawka pokazująca się na wiosnę (SKiel, 45), zmacha - (Chęciny), drab, olbrzym, w ogóle każden wielki (co do wzrostu) człowiek (SKiel, 49),

SPińcz: babiczka, krzew róży polnéj (SPińcz, 335), czajkiem, adv., niepostrzeżenie. „Czajkiem usłam ze zboża”. (SPińcz, 336), dworować, wychodzić na potrzebę na dwór. „Mojà matusia téj nocy nie dworowali”. (SPińcz, 336), fafuła, poléwka z jagod bzu czarnego (SPińcz, 336), haby, bielizna zamaczana w wodzie do prania (P336), gazdzić się, gapić się. „Posłasta na to, aby się tamok gazdzić” (SPińcz, 336), rdzonik, łupka smolnego drzewa (SPińcz, 338), sroczka, ostróżka polna (delphinium consolida Lin.) (SPińcz, 339), szczynki, plewy zebrane z różnego gatunku zboża (SPińcz, 339);

b) definicje zakresowe - pojawiają się tylko w kieleckim słowniczku ks. W. Siarkowskiego:

SKiel: fryć - u górników nazywa się początkujący chłopiec (SKiel, 39); japa - (pogardliwie) usta (SKiel, 39), kikuty - (pogardliwie) ręce (SKiel, 40), kinál - (pogardliwie) nos (SKiel, 40); krępy, -a, -e - (mówiąc o drzewie) skręcone, zwite, koślawe (SKiel, 40), kulásy - (zgrubiale) nożyska (SKiel, 40), micha - (pogardliwie) kobiéta nierodząca, bezdzietna (SKiel, 41); piokać - ledwie dychać (mówiąc o umierającym) np. ledwie pioká, ju piokać nié może (SKiel, 43);

c) definicje synonimiczne, których jest dość sporo w opisywanych słowniczkach ${ }^{21}$ : SKiel: bór - las; borowy - a, -e - leśny, np. borowá trawa - trawa leśna (SKiel, 37); beceć (beczeć) - płakać (SKiel, 36), galanty, - a, -e - piękny, nadobny (SKiel, 39), grąba miedza (Staro-Chęciny, SKiel, 39), grzdula - guz, wyrzut, bolak (SKiel, 39); krasiwo - omasta (SKiel, 40), poskuta - posługa (SKiel, 43); pozywiot - żywność (SKiel, 43), przegorzać się - przemawiać się, swarzyć się, np. ociec z matką przegorzali się (SKiel, 43), przeziéradko - zwierciadło (SKiel, 44), skiełki - bajki, pleciugi, np. já ciągle w domu siedze, na skiełki nikaj nie chodzę (SKiel, 45), sparka - ciepło, upał, przypieka słoneczna (SKiel, 45),

\footnotetext{
${ }^{21}$ Ze słowniczka sandomierskiego O. Kolberga podaję tylko niektóre przykłady: ciołak, cielę, cielątko (Kolberg 1865, 261), gościniec, karczma (Kolberg 1865, 261), omasta, okrasa, omaścić, okrasić, tłustością nasycić potrawę (L.) (Kolberg 1865, 263), swarzyć się, kłócić się (powszechne) (Kolberg 1865, 265).
} 
SPińcz: dychawka, duszność (SPińcz, 336), kaluga, kałuża (SPińcz, 336), reczka, tatarka (SPińcz, 338), głowacz, chaber, bławatek (centuarea cyanus Lin.) (SPińcz, 336), kozienica, sosna (SPińcz, 337), sałaga, nicpoń, włóczęga (SPińcz, 339).

Warto odnotować, że niektóre, mniej znane czytelnikowi synonimy, pojawiające się w definicji wyrazów hasłowych, nie stanowią odrębnych haseł (tu zostały wytluszczone). Nie zostały uwzględnione jako hasła słownikowe:

SKiel ciorać - walać, habrac ${ }^{22}$, zanieczyścić, np. państwo się pociorali kéj jechali do kościoła, bo dysc lunął. (Wyraz używany także w stopnickim powiecie i miechowskim) (SKiel, 37), śloch - $\boldsymbol{k o p e r w a s}^{23}$ (SKiel, 45), świetlaki - zacheuszki ${ }^{24}$ (nazwa kościelna) (SKiel, 45), licha - tiszkaa ${ }^{25}$, gąsiennica, plur. lichy, np. po hańtym ${ }^{26}$ drzewie chodzą lichy (SKiel, 40),

SPińcz: chargotać, psy chargotaly na dziada (SPińcz, 335), gwara: rajcować, dowodzić, wieść gwarę (SPińcz, 338).

\section{Informacje gramatyczne}

Informacje gramatyczne w słowniczkach dotyczą klasyfikacji części mowy: przysłówki, rzeczowniki, przymiotniki, form wyrazów: rzeczowników w M. 1.mn., D. 1.poj., form trybu rozkazującego czasowników, rodzaju gramatycznego ${ }^{27}$ :

SKiel: biedyćta (adv.) - tak, rzeczywiście, np. byłeś w domu? - biedyćta (SKiel, 36), chybie - (adver.) chyba, pewnie, zapewnie, np. panic chybie tu jesce nie był? (SKiel, 37); obraźnik (mascul.), obraźnicka (fem.) obrażający, -a kogo. (SKiel, 41), pałak, -ki (plur.) nizina, niziny zarosłe trawą, a znajdujące się między gruntami obsianymi zbożem (SKiel, 43), przywiśnie, (sub.) paraliż (SKiel, 44), licha - łiszka, gąsiennica, plur. lichy, np. po hańtym drzewie chodzą lichy (SKiel, 40), sady, - $a$, -e (adjec.) - ciemny, np. sady wół wyrzuca z pod siebie gnój (zagadka) (SKiel, 44), dhubek, genit. dłubka i femin. gener. powolny, guzdrała (K38), dymáć - spieszyć się, impert. dymáj, ruszaj! (SKiel, 38), ineli, -a, -e, (adjec.) równy; np. sytko bydło w oborze inele, nié ma ta (tam) mniejsego. (SKiel, 39), licha - łiszka, gąsiennica, plur. lichy, np. po hańtym drzewie chodzą lichy. (SKiel, 40), tluka, (subs. fem.) nierządnica. (SKiel, 46); wrzaskul - (subst. masc.) wrzeszczący, hałasujący (SKiel, 47), witka - biczysko (od: wić, subst. fem.) (SKiel, 47),

22 habrać; ciorać, p. ciarać 2.a. 'walać, brukać' (SWar 1900, I, 316).

23 koperwas *koperwaser, kuperwas 'nazwa potoczna siarczanów krystalizujących się z pięciu albo siedmiu cząsteczkami wody krystalicznej; nm. Kupferwasser’ (SWar 1902, II, 466).

${ }^{24}$ zacheuszek 'jedna z 12 świec w świeczkach przy krzyżach, znajdujących się na ścianach kościoła, w miejscach poświęcanych przy benedykcji kościoła’ (SWar 1927, VIII, 34).

25 Błędnie zam. $l$.

${ }^{26}$ hańty = tamten; hańten, hanta, hańto, hańtyn, hańty (SWar 1902, II, 156).

27 Przykłady z innego słowniczka gwarowego z tego okresu ze wsi Jaksice: gnać, cz. teraź. zene (żenę), zeniesz (Jaskłowski 1889, 91), hepać, cz. teraź. hepie się (Jaskłowski 1889, 91), samozyjca - kawaler (wymawiają nieraz samosyjca) (Jaskłowski 1889, 94). 
SPińcz: bliźnia, sub., sąsiadka (SPińcz, 335), całki, plur., rzepa (SPińcz, 335), czajkiem, adv., niepostrzeżenie (SPińcz, 336), heksdum, adv., natychmiast (Chroberz) (SPińcz, 336), kralaśny, adj., kulawy (SPińcz, 337), omnes, adv., zupełnie (Chroberz), wark, adj., niedobry, dokuczliwy (Morawica) (SPińcz, 339).

\section{Informacje o zasięgu geograficznym danego wyrazu}

Informacje o tym charakterze są zróżnicowane; odnoszą się do geografii zjawisk językowych, wiążą się ze wskazaniem miejsca użycia wyrazów (wymienione są nazwy wsi, powiatów, regionów, okolic $)^{28}$ :

SKiel: baraki - krzaki gęste (Brzezinki); barakiem nazywa się także dom przy lesie położony (SKiel, 36), bryzgać - (Brzeziny) brykać, np. kóń bryzga (SKiel, 37), ciorać - walać, habrać, zanieczyścić, np. państwo się pociorali kéj jechali do kościoła, bo dysc lunął. (Wyraz używany także w stopnickim powiecie i miechowskim) (SKiel, 37), dunaj - (subst. Daleszyce) przepaść, np. kamiéń wpad w głęboki dunaj (SKiel, 38); dziewcyca (Suchedniów, Bodzentyn) - dziewczyna (SKiel, 39), dzinie - (Masłów), drzewa wydrążone, w których pszczoły miód robią. (SKiel, 38), grajdała - (w krak. grajdos), niezgrabijasz (SKiel, 39), naflák - obcas u buta (Brzeziny) (SKiel, 41), nakrzyć - nagadać, np. nakrzyli ojcowie na mnie przed obcymi ludźmi różne rzecy. Siekierzno (SKiel, 41), swałek vel swałka - główka, np. urwáłem somsiadowi kilka swáłek kapusty w jego polu. Masłów. (SKiel, 45), trukta - (Brzeziny) włoszczyzna ogrodowa. (SKiel, 46), trzynąć vel trzunać - ruszyć się z miejsca, np. ludzie się trzunęli, jak ciandara (żandarm) zobacyli (Daleszyce) (SKiel, 46),

SPińcz: bezmian, w Krak., (Kolberg) przezmian - waga do mięsa (SPińcz, 335), grdykać, v. grdękać, zgrzędzić. Koło Kielc - pić wódkę (SPińcz, 336), heksdum, adv., natychmiast (Chroberz) (SPińcz, 336), omnes, adv., zupełnie (Chroberz) (SPińcz, 338), wark, adj., niedobry, dokuczliwy (Morawica) (SPińcz, 339), pasielaki mam dzieci, tj. takie, które ciągle należy karmić. (Włochy pod Pińczowem (SPińcz, 338).

\section{Kwalifikatory słownikowe}

Kwalifikatory słownikowe stanowią jeden z elementów informacji słownikowych. Służą one do charakterystyki wyrazów, ich znaczeń lub użyć pod względem stopnia rozpowszechnienia, zasięgu geograficznego i wartości stylistycznej lub rzadko: charakteru społeczno-środowiskowego (zob. Dubisz 2011; Engelking-Teleżyńska, Markowski, Weiss 1989):

${ }^{28}$ Zob. np. kotłować, męczyć uwagę rozmową, np. głowę mi zakotuował (w Warsz. burzyć, burzyć się), śratać, pośratać sie, zbratać się z kim, zaprzyjaźnić, pokumać, witać, lub żegnać serdecznie. S. Opatows. Lubel. (Kolberg, 1865, 265), stykot, styk narzędzie, którèm się wygarnia ziemię z pługa. (L.) styk, istyk, w Krak: i u Górali (Kolberg 1865, 264). 
a) kwalifikatory frekwencyjne - wyrazy sygnowane jako rzadko używane ${ }^{29}$ : SKiel: ocenzerować - obgadać, (wyraz ten bardzo rzadko używany) (SKiel, 42), odchmálić (rzadko używane) - otworzyć, np. trza odchmálić drzwi, bo parno w izbie (SKiel, 42),

SPińcz: naskórkać, nakląć (rzadko używa się) (SPińcz, 337);

b) kwalifikatory stylistyczne (ekspresywne) i społeczno-środowiskowe odnoszą się do kilkunastu wyrazów ${ }^{30}$ :

SKiel: ciarapata - (przezwisko pogardliwe), udający, przedstawiający się za szlachcica, a nie mający klejnotu szlacheckiego (SKiel, 37), fryć - u górników nazywa się początkujący chłopiec (SKiel, 39); żuzek-a vel zusek - (górniczy wyraz) kawałek żelaza. (Co innego: żuzel, odpadek przy topieniu żelaza) (SKiel, 49), granda - rozbój nocny, grandować - rozbijać w nocy. (Wraz ${ }^{31}$ złodziejski) (SKiel, 39), japa - pogardliwie usta (SKiel, 39), kikuty - (pogardliwie) ręce (SKiel, 40), kinál - pogardliwie nos (SKiel, 40); krępy, -a,-e - (mówiąc o drzewie) skręcone, zwite, koślawe (SKiel, 40), kulásy - (zgrubiale) nożyska (K40), micha - (pogardliwie) kobiéta nierodząca, bezdzietna (SKiel, 41); piokać - ledwie dychać (mówiąc o umierającym) np. ledwie pioká, ju piokać nié moze (SKiel, 43).

Żadne z nich nie pojawiają się w słowniczku pińczowskim.

\section{Informacje etymologiczne}

Informacje o pochodzeniu wyrazów nie są obecne w omawianych zbiorkach leksyki. Dodajmy, że rzadko też pojawiają się w słowniczku Kolberga z Sandomierskiego czy W. Jaskłowskiego z Jaksic ${ }^{32}$.

\footnotetext{
${ }^{29}$ Występują one w innych słowniczkach regionalnych: w słowniczku z Sandomierskiego O. Kolberga oraz w jaksickim słowniczku W. Jaskłowskiego. Mamy tu informacje o częstym występowaniu tych wyrazów, stąd kwalifikator powszechne i jeden wyraz oznaczony jako rzadko używa się: ciołak, cielę, cielątko (powszechne) (Kolberg 1865, 261), doma, w domu (L.) powszechne (Kolberg 1865, 261), k'sobie, odsiebie, na lewo, na prawo (powszechne) (Kolberg 1865, 262), lelija, lilija (powszechne) (Kolberg 1865, 262), pono, podobno (powszechne) (Kolberg 1865, 264), rejwach, krzątanie się (powszechne) (Kolberg 1865, 264), cosik, coś: powszechnie znane (Jaskłowski 1889, 93), duchem, prędko (powszechne) (Jaskłowski 1889, 91), ostawić, zostawić (powszechne) (Jaskłowski 1889, 93), niechàj, nieruszaj (powszechne) (Jaskłowski 1889, 93), niezdarzony, niezgrabny (powszechne) (Jaskłowski 1889, 93), zabaczyć, zapomnieć (powsz.) (Jaskłowski 1889,98$)$.

${ }^{30}$ Ze słowniczka O. Kolberga z Sandomierskiego wynotowano następujące przykłady: furda, fraszka (pogardliwe) (Kolberg 1865, 261), kiecka, spódnica (pogardliwe) (Jaskłowski 1889, 92), ludowina, ludek (zdrobniale) (Kolberg 1865, 263), okara, człek lub zwierzę niezgrabne (pogardliwe), szpetne na ciele i duszy, nieudolne. S. (L.) (Kolberg 1865, 263), upatrzyć, dojrzeć zająca w kotlinie (myśliwskie wyrażenie) (Kolberg 1865, 265).

31 Zamiast wyraz.

32 Rzadko też pojawiają się w słowniczkach O.Kolberga z Sandomierskiego i W. Jaskłowskiego z Jaksic: gruba z Niem: (L. gruba, jama, loch) (Kolberg 1865, 262), heco; hecować, objeżdżać śpiącego zająca np. óni gadają a ja hecuję (L.) z niem. Hetzen (Kolberg 1865, 262), lada, skrzynka do rznięcia ręcznego sieczki (L.) powszechne (z niem. Lade) (Kolberg 1865, 262), lidkup, picie na zgodę (jak na Rusi mohorycz). (L. litkup), szachraj, szachraj, szachraj, oszukaniec (o żydach, z niem. Schacher) (Kolberg 1865, 264), świedlerz, świedlirz, oszust, uwodziciel (może od Schwindler?) (Kolberg 1865, 265), brewiter, brewidnie
} 


\section{Odsyłacze}

W słowniczkach przy niektórych wyrazach pojawia się odesłanie do poświadczenia danego wyrazu w Słowniku języka polskiego B.S. Lindego (skrót: L): cieciora, soczewica. W słown. Lindego - groch włoski (SPińcz, 336), gorlić się, przegorlać się, przemawiać się. W słown. Lindego słowo to ma odmienne znaczenie. (SPińcz, 336), gruzołek, (U Lindego gruzołka) - bryłka, grudka (SPińcz, 336).

\section{Zakończenie}

Charakteryzowane przeze mnie dwa słowniczki gwarowe ks. W. Siarkowskiego, będące świadectwem jego zainteresowań regionalnych, przyczyniają się - jak wspomniano - do pomnożenia dziewiętnastowiecznego dorobku polskiej leksykografii gwarowej. Są nie tylko doskonałymi źródłami do historii badań gwar Małopolski środkowo-północnej (i gwar polskich w ogóle), ale umożliwiają poznanie warsztatu leksykograficznego jego autora ${ }^{33}$. O ich ważności przekonuje fakt, że są źródłami dokumentacji wyrazowej największych opracowań polskiej leksykografii gwarowej. Słowniczki te zawierają najstarszą leksykę gwar Małopolski środkowo-północnej. Jej porównanie $\mathrm{z}$ materiałami aktualnie gromadzonymi $\mathrm{w}$ trakcie badań terenowych może ukazać zmiany leksyki w przestrzeni czasowej ${ }^{34}$.

\section{Literatura}

Bartnicka B. (1997), Władysław Matlakowski jako dialektolog, [w:] Polszczyzna Mazowsza i Podlasia. Śladami Kolberga i Glogera po ziemi tomżyńskiej, Łomża, s. 19-25.

Biela J. (1891), Spis wyrazów zebranych we wsi Żarnówce nad Skawa, „Sprawozdania Komisji Językowej Akademii Umiejętności”, IV, s. 374-384.

Bystroń J.S. (1937), Andrzej Cinciała, [w:] Polski Stownik Biograficzny, t. III, Kraków, s. 76.

\footnotetext{
- prawdziwie, otwarcie, wprost (breviter?) (Jaskłowski 1889, 90), kalkuruwać, kombinować, pojmować (calcurare) (Jaskłowski 1889, 92), wymarzyć się, wymienić się na co (Linde frymarczyć, n. freimarkt) (Jaskłowski 1889,96$)$.

${ }^{33}$ Dawne działania inteligentów były konieczne dla utrzymania ciągłości i tożsamości narodowej i naukowej, i to była ich pierwszoplanowa rola. Jesteśmy spadkobiercami pewnej tradycji leksykograficznej, doskonalonej przez lata, zapoczątkowanej przez amatorów, a później przez twórcę dialektologii polskiej L. Malinowskiego, a kontynuowanych z powodzeniem przez uczniów z jego szkoły językoznawczej, m.in. J. Bieli, G. Blatta, J. Bystronia, S. Dobrzyckiego, J. Hanusza, J. Leciejewskiego, J. Łosia, Sz. Matusiaka, K. Nitscha, J. Rozwadowskiego, I. Steina, R. Zawilińskiego.

${ }^{34} \mathrm{Na}$ przykład porównanie wyrazów jaksickich ze słowniczka Z. Wasilewskiego z wyrazami z sąsiedniej wsi, odległej $1 \mathrm{~km}$ od wsi Książnice Wielkie, rodzinnej wsi W. Kupiszewskiego, pozwoliło uchwycić Autorowi zmiany w słownictwie po 100 latach: są tu wyrazy „wyszłe” z użycia, ginące (gasnące) słowa i wyrazy, które przetrwały do dziś: jednostki, które zaginęły stanowią $22 \%$, jednostki, w których zaszły zmiany $-31 \%$, jednostki, które pozostały bez zmian $-47 \%$ (zob. Kupiszewski 2011; por. np. w odniesieniu do zmian w zakresie nazw potraw mój artykuł: Cygan 2003).
} 
Cinciała A. (1998), Stownik dyalektyczny Księstwa Cieszyńskiego z dodatkiem przysłowiów i frazeologii [reprodukcja fotooffsetowa $\mathrm{z}$ rękopisu], Wisła.

Cinciała A. (1931), Pamiętnik dra Andrzeja Cinciaty notariusza w Cieszynie (1825-1898), Katowice.

Cygan S. (1997), Stan badań nad gwarami kieleckimi, [w:] Tradycja badań dialektologicznych w Polsce. Księga referatów z sesji językoznawczej w Olsztynie, pod red. H. Sędziak, Olsztyn, s. $102-118$.

Cygan S. (1998), Ksiadz Władysław Siarkowski (1840-1902) jako dialektolog-amator, [w:] Studia językoznawcze. Praca zbiorowa, pod red. W. Kupiszewskiego, Kielce - Warszawa, s. $97-106$.

Cygan S. (2002), Gwara w pracach etnograficznych Zygmunta Wasilewskiego, [w:] Zygmunt Wasilewski - polityk - krytyk - regionalista, pod red. M. Meduckiej, Kielce, s. 145-160.

Cygan S. (2003), Materiały etnograficzne z okolic Pińczowa księdza Władysława Siarkowskiego jako źródto do badań nad gwarami polskimi, [w:] Ks. W. Siarkowski, Materiaty do etnografii ludu polskiego z okolic Pińczowa, do druku przygotowali K. Bracha, B. Wojciechowska i L. Michalska-Bracha, Kielce, s. LXXIII-XC.

Cygan S. (2005), Ludoznawcze zainteresowania kieleckiej inteligencji, [w:] Z tradycji i dorobku inteligencji kieleckiej $w$ XIX $i$ XX wieku, pod red. M. Meduckiej, Kielce, s. 11-27.

Cygan S. (2009), Mniej znane quasi-kwestionariusze do badań dialektów polskich, „Poradnik Językowy", z. 9, s. 59-75.

Cygan S. (2015), Trzy dziewiętnastowieczne małopolskie słowniczki gwarowe, „Poradnik Językowy", z. 10, s. 7-23.

Dembowski B. (1891), Spis wyrazów i wyrazów używanych na Podhalu jako uzupetnienie poprzednich zbiorów, „Sprawozdania Komisji Językowej Akademii Umiejętności”, IV, s. 301-317.

Doroszewski W. (1953), Przedmiot i metody dialektologii, „Poradnik Językowy, z. 4, s. 4-12.

Dubisz S. (2011), Kwalifikatory w stowniku - problem nie tylko leksykograficzny, „Prace Filologiczne", t. LX, s. 99-108.

Engelking-Teleżyńska E., Markowski A., Weiss E. (1989), Kwalifikatory w słownikach - próba systematyzacji, „Poradnik Językowy”, z. 5, s. 300-309.

Filas A., Janecki S. (1998), Umierajaca klasa. Polska inteligencja jako formacja należy do przeszłości, współpraca P. Moszyński, J. Szczęsny, „Wprost”, 22 listopada 1998, s. 24-28.

Gloger Z. (1893), Słownik gwary ludowej w okręu tykocińskim, „Prace Filologiczne”, t. IV, s. $795-904$.

Górski R. (1974), Oskar Kolberg. Zarys życia i działalności, Warszawa.

Gruchmanowa M. (1998), O. Kolberg jako gwaroznawca, [w:] Oskar Kolberg 1814-1890. Materiaty sesji naukowej. Kraków, 26 XI 1994, Kraków, s. 29-34.

Jaskłowski Z. (1889), Słowniczek wyrazów ludowych we wsi Jaksicach, „Prace Filologiczne”, t. V, s. $90-98$.

Kapuścik J. (1995), Władystaw Matlakowski. Lekarz-pisarz-uczony, Warszawa.

Karaś H. (2011), Polska leksykografia gwarowa, Warszawa.

Karaś H. (2012), Dziewiętnastowieczne słowniczki gwarowe jako przedmiot badań językoznawczych, „Poradnik Językowy”, z. 1, s. 55-64.

Karaś H. (2013), Stowniczek gwar wielkopolskich Oskara Kolberga w dziejach polskiej leksykografii gwarowej, [w:] Cum reverentia, gratia, amicitia... Ksiegga jubileuszowa dedykowana 
Profesorowi Bogdanowi Walczakowi, t. II, pod red. J. Migdał i A. Piotrowskiej-Wojaczyk, Poznań, s. 33-44.

Karłowicz J. (1871), Poradnik dla zbierajacych rzeczy ludowe, Warszawa.

Kiniowski M. (1937), Chełchowski Stanisław, [w:] Polski Słownik Biograficzny, t. III, Kraków, s. $271-272$.

Kolberg O. (1865), Lud. Jego zwyczaje, sposób życia, mowa, podania, przysłowia, obrzędy, gusła, zabawy, pieśni, muzyka i tańce. Sandomierskie, Warszawa.

Kolberg O. (1965), Dzieła wszystkie, t. 64: Korespondencja Oskara Koberga, część I (18371876), Wrocław - Poznań.

Kolberg O. (1966), Dzieła wszystkie. T. 65: Korespondencja Oskara Koberga, czesść II (18771882), Wrocław - Poznań.

Koniusz E. (2007), Materiaty księdza Władysław Siarkowskiego w Stowniku gwar polskich Jana Karlowicza, [w:] W kręgu dialektów i folkloru. Prace ofiarowane Doktor Teresie Golębiowskiej, Docent Wandzie Pomianowskiej i Docent Zofii Stamirowskiej, pod red. S. Cygana, Kielce, s. 107-119.

Kowalska-Lewicka A. (1975), Władysław Matlakowski, [w:] Polski Słownik Biograficzny, t. XX, Wrocław - Warszawa - Kraków - Gdańsk, s. 205-206.

Krzyżanowski J. (1965a), Stanisław Chełchowski, [w:] Stownik folkloru polskiego, red. J. Krzyżanowski, Warszawa.

Krzyżanowski J. (1965b), Andrzej Cinciała [w:] Stownik folkloru polskiego, red. J. Krzyżanowski, Warszawa.

Krzyżanowski J. (1965c), Karol Mátyás, [w:] Słownik folkloru polskiego, red. J. Krzyżanowski, Warszawa.

Kupiszewski W. (2011), Co z tego pozostało? (O pewnej gwarze po stu latach), „Prace Filologiczne", t. LXII, s. 155-162.

Linde M.S.B. (1951), Stownik języka polskiego, t. V, wyd. III, Warszawa.

Łoś J. (1904), Znaczenie „Słownika gwar polskich”, [w:] Życie i prace Jana Kartowicza (1836-1903). Książka zbiorowa wydana staraniem i nakładem redakcji „Wisły”, Warszawa, s. $176-180$.

Malinowski L. (1873), Beiträge zur slavischen Dialectologie. I. Ueber die oppelnsche Mundart in Oberschlesien. (1. Heft: Laut- und Formenlehre), Leipzig.

Matlakowski W. (1891), Zbiór wyrazów ludowych dawnej Ziemi Czerskiej, „Sprawozdania Komisji Językowej Akademii Umiejętności”, IV, s. 362-373.

Matlakowski W. (1894), Słownik wyrazów ludowych zebranych w Czerskiem na Kujawach, „Sprawozdania Komisji Językowej Akademii Umiejętności”, V, s. 127-147.

Mátyás K. (1891), Stowniczek gwary ludu zamieszkującego wschodnio-południowa najbliższa okolicę Nowego Sącza (wsie: Zawada, Nawojówka, Brzeziny, Kunów, Jamnica, Poręba, Bielowice i Dąbrówka Polska), „Sprawozdania Komisji Językowej Akademii Umiejętności”, IV, s. $318-335$.

Miodunka W. (1989), Podstawy leksykologii i leksykografii, Warszawa.

Najder Z. (2000), Od stużby do nostalgicznego mitu, „Rzeczpospolita” nr 22 (388) z 3-4 czerwca.

Nowowiejski B. (2003), „Stowniczek gwary augustowskiej” Aleksandra Osipowicza jako rekonstruowane źródto do historii polskiej leksykografii gwarowej, [w:] Gwary dziś, t. 2: Regionalne stowniki i atlasy gwarowe, pod red. J. Sierociuka, Poznań, s. 97-102. 
Nowowiejski B. (2007), Z warsztatu leksykograficznego Ludwika Czarkowskiego, [w:] Gwary dziś t. 4: Konteksty dialektologii, pod red. J. Sierociuka, Poznań, s. 263-273.

Nowowiejski B. (2009a), Przekładowy stownik niemiecko-polski z połowy XIX wieku jako zapis językowej świadomości słownikarza, [w:] Synchroniczne i diachroniczne aspekty badań polszczyzny, t. 8, Szczecin, s. 83-93.

Nowowiejski B. (2009b), Zapomniane słownictwo z połowy XIX wieku, „Białostockie Archiwum Językowe", nr 9, s. 217-231.

Nowowiejski B. (2010a), Z warsztatu leksykograficznego Krzysztofa Celestyna Mrongowiusza, [w:] Język polski - wczoraj - dziś - jutro, pod red. B. Czopek-Kopciuch i P. Żmigrodzkiego, Kraków, s. 176-183.

Nowowiejski B. (2010b), Wychowawczy wymiar słowników niemiecko-polskich z XIX w., „Białostockie Archiwum Językowe", nr 10, s. 203-214.

Nowowiejski B. (2013), Stownik Mrongowiusza - między Lindem a stownikiem wileńskim, „Prace Filologiczne", t. LXIV, s. 225-244.

Pelcowa H. (2003), Synonimia i wieloznaczność w stowniku gwarowym, [w:] Gwary dziś, t. 2: Regionalne stowniki i atlasy gwarowe, pod red. J. Sierociuka, Poznań, s. 203-216.

Reichan J., Woźniak K. (2001), Perspektywy polskiej leksykografii gwarowej, [w:] Gwary dziś, t. 1: Metodologia badań, pod red. J. Sierociuka, Poznań, s. 33-42.

Rembiszewska D.K. (2010), Stownik dialektu knyszyńskiego a inne stowniczki gwarowe z obszaru pótnocno-wschodniej Polski, „Prace Filologiczne”, t. LVIII, s. 345-361.

Rzeszowski L. (1891), Spis wyrazów ludowych z okolicy Żywca, „Sprawozdania Komisji Językowej Akademii Umiejętności”, IV, s. 353-361.

Ks. Siarkowski W. (1878-1880), Materyaty do etnografii ludu polskiego z okolic Kielc, cz. 1-3, Kraków, [odb. z:] „Zbiór Wiadomości do Antropologii Krajowej”, 1878, t. 2, s. 209-259, 1879 , t. 3, s. 3-61, 1880, t. 4, s. 83-184, [przedruk w:] Ks. W. Siarkowski, Materiaty do etnografii ludu polskiego $z$ okolic Kielc, do druku przygotowali L. Michalska-Bracha i K. Bracha, Kielce 2000.

SGP, Słownik gwar polskich. Źródła, oprac. przez Zakład Dialektologii Polskiej Instytutu Języka Polskiego PAN w Krakowie pod kier. M. Karasia, Wrocław - Warszawa - Kraków - Gdańsk, 1977.

SKarł, Karłowicz J. (1900-1911), Stownik gwar polskich, t. I-VI, Kraków.

SWar, Słownik języka polskiego [tzw. warszawski], red. J. Karłowicz, A.A. Kryński, W. Niedźwiedzki, Warszawa 1900-1927.

SWil, Stownik wileński, cz. I-II, Wilno, 1861.

Skrukwa A. (2014), Oskar Kolberg 1814-1890, Poznań.

Sokólska U. (2013), Przyczynki do projektu Wielkiego słownika polskiego Jana Karłowicza jako źródto wiedzy o warsztacie leksykografa końca XIX wieku, „Prace Filologiczne”, s. 351-366.

Surdykowski J. (1998), Żywy umyst, „Wprost” 22 grudnia 1998, s. 36-37.

Tomaszewska E. (2015), Oskar Kolberg $i$ ks. Władysław Siarkowski-wspótpraca $i$ wkład w dokumentację kultury ludowej Kielecczyzny, [w:] Ja daję wtaśnie materiat... O dziele Oskara Kolberga w dwusetna rocznice Jego urodzin, pod red. E. Antyborzec, Poznań, s. 329-337.

Tyrpa A. (2015), Językoznawstwo w Dziełach wszystkich Oskara Kolberga, [w:] Ja daję właśnie materiat... O dziele Oskara Kolberga $w$ dwusetna rocznice Jego urodzin, pod red. E. Antyborzec, Poznań, s. 91-108. 
Urbańczyk S. (1993), Dwieście lat polskiego językoznawstwa (1751-1950), Kraków.

Waga A. (1860), Abecadłowy spis wyrazów ludowego języka w okolicach Łomży, Wizny i przyległych, „Biblioteka Warszawska”, t. II, s. 748-760.

Wojtkiewicz I. (2003), O „Słowniczku gwary augustowskiej” Aleksandra Osipowicza, [w:] Słowa jak mosty nad wiekami, red. U. Sokólska, P. Wróblewski, Białystok, s. 287-297.

Woźniak K. (2000), Stan polskiej leksykografii gwarowej pod koniec XX wieku, [w:] Stowiańskie stowniki gwarowe, pod red. H. Popowskiej-Taborskiej, Warszawa, s. 17-51.

Wronicz J. (2010), Maty stownik gwar polskich, „Prace Filologiczne”, t. LVIII, s. 457-469.

Wysoczański W. (2015), Materiały językowe w Kolbergowskim przekazie źródłowym, [w:] Ja daję wtaśnie materiat... O dziele Oskara Kolberga w dwusetna rocznicę Jego urodzin, pod red. E. Antyborzec, Poznań, s. 107-124.

Zawiliński R. (1887), O sposobie gromadzenia materyatów etnograficznych, „Wisła”, t. I, s. 3-8; s. $43-48$.

Złoża J. (1891), Zbiór wyrazów używanych w okolicach Chochołowa, „Sprawozdania Komisji Językowej Akademii Umiejętności”, IV, s. 341-352.

Żeromski S. (1929), Snobizm i postęp, Warszawa - Kraków.

Żmigrodzki P. (2003), Wprowadzenie do leksykografii polskiej, Katowice.

Żyga A. (1975), Mátyás Karol Marian, [w:] Polski Słownik Biograficzny, Wrocław - Warszawa Kraków - Gdańsk. 